\title{
ELECTRIFICATION OF PUBLIC TRANSPORT BUS FLEET: IDENTIFICATION OF BUSINESS AND FINANCING MODELS
}

\author{
Grzegorz Dydkowski ${ }^{1}$, Jozef Gnap ${ }^{2, *}$, Anna Urbanek ${ }^{1}$ \\ ${ }^{1}$ Department of Transport, University of Economics in Katowice, Katowice, Poland \\ ${ }^{2}$ Department of Road and Urban Transport, Faculty of Operation and Economics of Transport and Communications, \\ University of Zilina, Zilina, Slovakia
}

*E-mail of corresponding author: jozef.gnap@fpedas.uniza.sk

\section{Resume}

The paper presents possible models of electric buses purchase financing, taking into account purchase prices higher now than in the case of traditional buses. During the research, the solutions used on several continents and in many countries were analysed, including the USA, China and many European countries. The qualitative research methods were used, focusing less on the describing and dimensioning the current state and more on creating and presenting theories and the implementation proposals themselves. As a result, it also allowed to include issues related to applicability and implications of formulated solutions for managerial practice.

\section{Article info}

Received 21 September 2020

Accepted 26 November 2020

Online 26 March 2021

\section{Keywords:}

electromobility,

electric buses,

financing,

financing public transport

\section{Introduction}

Introduction of the city servicing by electric buses, not only within the scope limited to a few lines and as a pilot project, but to a significant extent of carried out transport, will require financing to be ensured - both for procurement of buses themselves, as well as of the necessary infrastructure. The financing of infrastructure and buses purchase are related projects, in terms of time and scope they must proceed in such a way that services provision would be possible; however, the financing methods and sources may differ. As a rule, the infrastructure is managed and financed by the public entities and from public funds - various level budgets, depending on its purpose and function carried out in a given country system. The vehicles financing and purchase in most cities worldwide was and is the domain of operators themselves (these entities do not need involvement of public capital), because as a rule it is them, who are obliged to ensure means of transport necessary to provide services. Electric buses are now significantly more expensive than traditional ones, i.e. driven by internal combustion engines. Anyway, the charging infrastructure and purchase of buses themselves do not comprise all the expenditures. An assumption may be made that for many years operators will be using both traditional buses with combustion engines and electric buses. This will result in a necessity to maintain the hitherto technical facilities for traditional buses and to provide additional equipment and also to employ people qualified to service and repair electric buses, which will also increase the costs [1].

Electric buses are more environment friendly at the place of service provision, hence significant external benefits are achieved. Apart from benefits, related to emissions cutting, reduction of dependence on liquid fuels is important, as well. Crude oil markets feature limited stability, there are numerous tensions and disturbances in some of extracting it countries [2], moreover there are numerous indications that the era of fossil fuels comes to an end due to their deposits depletion - at the current consumption rate the resources are estimated at approx. 40 years. Obviously, the Earth has still significant oil resources in shale and bituminous sands, in the Arctic, Amazonia and under oceans bottom (at great depths), but the costs of their extraction will be much higher than the extraction of reservoirs today. Thus, one can say that the era of cheap oil comes to an end [3].

When introducing electric buses to operation it is difficult to assume that the necessary additional funds will be obtained from growing revenues on sales of services; quite opposite - the spatial development of cities, population concentration in big cities and processes proceeding there cause the urban public transport to be more and more capital intensive, which results in growing demand for public financing [4-6]. 
Table 1 Purchase prices and estimated usage time of buses [8]

\begin{tabular}{ccc}
\hline technology & capital expenditure (EUR) & depreciation (years) \\
\hline diesel euro VI & 230,000 & 10 \\
CNG euro VI & 270,000 & 10 \\
PHEV euro VI & 445,000 & 10 \\
electric (with battery) & 502,500 & 10 \\
electric (with battery leased) & 475,000 & 10 \\
\hline
\end{tabular}

Table 2 Forecast of battery prices (EUR/ $k W h$ ) depending on demand for electric buses in Europe [1]

\begin{tabular}{lcccccccc}
\hline battery price for buses (EUR/kWh) & 2016 & 2018 & 2020 & 2022 & 2024 & 2026 & 2028 & 2030 \\
\hline low demand in European e-bus & 510 & 333 & 269 & 224 & 194 & 167 & 146 & 129 \\
high demand in European e-bus & 510 & 333 & 262 & 204 & 160 & 122 & 102 & 85 \\
variation low vs. high demand & & & $-3 \%$ & $-9 \%$ & $-18 \%$ & $-27 \%$ & $-30 \%$ & $-34 \%$ \\
\hline
\end{tabular}

Their limited range and time necessary to recharge the battery add to that, reducing the time during which they can be used to serve lines.

As an assumption, the service users pay for the service of moving and this service - understood as location change within a specific time - not necessarily depends on the fact whether a passenger moves by a bus with a combustion engine, or a bus with an electric motor. Obviously, in the case of electric buses it is emphasised that the motor operation is quieter and thereby the noise level lower, vibrations are smaller than those generated by combustion engines, there is no exhaust gas emission, especially when the bus approaches and waits on a stop, as well as the very feeling of moving by a zero-emission and modern vehicle [1]. However, these factors not necessarily cause a significant increase in the number of passengers using the public transport. Individual methods of movement, primarily by cars, remain the competition all the time. In the case of increased prices of the public transport services it is necessary to take into account a decline of demand for those services and an increased number of movements by cars, which in practice may cancel the reduction of environmental impact, which is expected to be achieved as a result of electric buses introduction to operation. Of course, one can refer to ecological awareness, however, it is not necessarily considered when making decisions about a method to move. It is proved by a significant share of journeys by private cars in cities and ineffectiveness of numerous tools, which for years were used trying to reduce the car traffic.

\section{Materials and methods}

\subsection{Background of the research}

The difference of prices between the electric and combustion buses depends on the world's region, the size of single procurement order, equipment, battery size and hence range, applied design solutions, guarantee conditions and other factors. Numerous analyses emphasise the fact that an electric bus is now roughly twice more expensive than a traditional bus with a combustion engine (Table 1) [7-8]. This is now the basic barrier to the order sizes growth [9], another barrier is the fact that external costs are not entirely or only to a small extent taken into account as evaluation criteria in the bidding procedures for vehicles purchase [1].

The zero-emission nature of electric buses affects expectations of their widespread use in cities, which in turn is related to the necessity of incurring high financial expenditures. Thus, a question arises to what extent it is possible to acquire additional funds, because of the better management of possessed resources and urban transport management, so that substantial purchases could be financed, at the same time additionally burdening the public budgets in a limited way. Each additional public expenditure means either funds originating from the better management of the existing resources or giving up other public tasks, or an increase in the tax burden now or in the future. Therefore, considerations should be broader, to what extent an increase in the public sector operation effectiveness is possible and how to finance vehicles purchases, so that the created solution would provide funds, but also would result in effective use of the purchased vehicles.

A part of available analyses forecast and expect that - with increasing amounts of purchases and further technology development - purchase prices of ecologically clean vehicles will decline, including primarily electric buses. Attention is drawn to the fact that the batteries and solutions for electricity charging management and electricity consumption are new and innovative ones and with the increasing demand and thereby production size the unit manufacturing cost will be going down. Table 2 presents the forecast of battery prices (EUR/kWh).

According to economic forecasts, assuming a scenario of high demand, it is expected that the battery prices will decrease to about $1 / 3$ of current prices over the next 10 years. In addition, the lower operation and maintenance costs of electric buses are emphasised, which should result from a simpler structure of driving units and lower costs related to consumption of energy 
Table 3 Overview of the TCO per technology [8]

\begin{tabular}{|c|c|c|c|c|c|c|c|}
\hline & \multirow{2}{*}{ diesel } & \multirow{2}{*}{ CNG } & \multirow{2}{*}{ PHEV } & \multicolumn{2}{|c|}{ BEV (opportunity charging) } & \multicolumn{2}{|c|}{ BEV (depot charging) } \\
\hline & & & & with battery & lease & with battery & lease \\
\hline fuel cost (EUR/km) & 0.43 & 0.29 & 0.33 & 0.10 & 0.10 & 0.10 & 0.10 \\
\hline $\begin{array}{l}\text { maintenance cost } \\
(\mathrm{EUR} / \mathrm{km})\end{array}$ & 0.42 & 0.53 & 0.28 & 0.23 & 0.23 & 0.23 & 0.23 \\
\hline $\begin{array}{l}\text { battery lease } \\
(\mathrm{EUR} / \mathrm{km})\end{array}$ & - & - & - & - & 0.14 & - & 0.14 \\
\hline $\begin{array}{l}\text { battery replacement } \\
(\mathrm{EUR} / \mathrm{km})\end{array}$ & - & & 0.002 & 0.013 & - & 0.025 & - \\
\hline $\begin{array}{l}\text { insurance costs } \\
(\mathrm{EUR} / \mathrm{km})\end{array}$ & 0.09 & 0.09 & 0.09 & 0.09 & 0.09 & 0.09 & 0.09 \\
\hline tax cost (EUR/km) & - & - & - & - & - & - & - \\
\hline Subsidies & - & - & - & - & - & - & - \\
\hline $\begin{array}{l}\text { operational } \\
\text { expenditures } \\
10 \text { years }(\mathrm{EUR} / \mathrm{km})\end{array}$ & 0.93 & 0.91 & 0.70 & 0.42 & 0.55 & 0.44 & 0.55 \\
\hline $\begin{array}{l}\text { capital expenditures } \\
\text { bus }\end{array}$ & 184,719 & 216,844 & 357,391 & 403,571 & 381,485 & 403,571 & 381,485 \\
\hline $\begin{array}{l}\text { infrastructure + } \\
\text { maintenance }\end{array}$ & $2,509.37$ & $5,120.48$ & $8,618.18$ & $83,773.96$ & $83,773.96$ & $24,435.24$ & $24,435.24$ \\
\hline $\begin{array}{l}\text { TCO } 10 \text { years } \\
(\text { EUR/km) }\end{array}$ & 1.24 & 1.27 & 1.32 & 1.24 & 1.33 & 1.18 & 1.23 \\
\hline
\end{tabular}

to drive vehicles. All that should cause that the total costs of ownership (TCO), calculated as the cost of purchase and then operating costs of electric buses, in the future will be comparable to traditional buses [8, 10]. The study conducted by Hooftman et al. [8] shows that the unit TCO for 10 years usage may be similar for different technologies (Table 3). When calculating financial flows the residual value of bus batteries may be taken into account, which could be used within the so-called second life, i.e. in energy storage facilities [11]. Apart from the higher expenditures for the purchase, the electric buses operation is related also to such risks as batteries durability and possible decline of their capacity, which over time can affect buses capability to carry out transport on a hitherto transport line.

Research carried out in various countries pursues development of a new model - method for vehicles purchase financing, in particular electric buses [12-16]. Obviously, the well-known assets financing methods are used, but realities related to specific investments - which in this case are electric buses - are considered [17]. The basic problem when considering the investment issues consists in answering a question, how to invest, i.e. what should be the origin of funds and how they should be directed, since a good investing system should ensure:

- effective use of funds allocated for investments,

- effective operation of fixed assets acquired as a result of investment activity,

- stimulation of reaching the structure of transport market assumed by the public authorities.

In most cases operators are publicly owned - by municipalities, intermunicipal unions, or other public administration entities; that depend on solutions adopted in a specific country. They operate as commercial companies, with entities from the public finance sector as shareholders or stockholders, or pursuant to regulations indented for public sector entities. Operators also include entities with private capital involvement [18]. It is necessary, as far as possible, to create equal access conditions to the capital for electric buses purchase, both for entities from the public and private sector.

\subsection{Methods}

The paper focuses the consideration on the method of electric buses financing, so that the financing model would take into account peculiarities related to the new solution implementation. This issue is a challenge on all the continents or in all the countries introducing electric buses [9]. It is also necessary to examine, to what extent systemic solutions could cause that bigger amounts of funds, indispensable to engage by urban public transport operators, not necessarily burden budgets from which the urban public transport investments and services are financed - for example in the case of acquiring the nonrepayable external funds, which co-finance now and in the future projects of electric buses implementation. At the same time, it is necessary to consider that external funds, originating from the European Union budget, are obtained from various tax burdens and only their flow is diversified.

Basic information sources used during the research comprise comprehensive studies from the field of public 
sector finance, analyses, communications, assessments and transport development scenarios, documents related to the transport development policy and strategy and the best practice examples, as well. Apart from published materials, websites of the European Union institutions, scientific and research centres, governments and local authorities of various states of the world, were used.

Taking into account the subject and the aim of the study, qualitative research methods were used. Recognizing the significant importance of quantitative methods and observing the far-reaching domination of quantitative research in economic sciences, it should be noted that the quantitative research primarily provides answers to basic questions related to the number and frequency of solutions or allows to draw conclusions about the entire population based on the studied sample. In the quantitative research, the aim is to determine the quantitative dependencies of the studied phenomena, paying particular attention to the correctness of the determined variables and the measurement logic [19]. This attitude allows for establishing facts, quantifying the existing state and checking statistical relationships, but it is limited in creating theories and formulating proposals [20]. It is the qualitative methods that focus less on the frequency of the solutions or phenomena studied and more on the description, presentation and development of theories and related good practices. Qualitative methods allow obtaining answers to basic questions - why and how a given phenomenon takes place, as these methods aim to understand and determine the motives of such actions and behaviour [21]. The created theory is general to a certain degree and there are reservations in terms of its practical application. The main role of qualitative research is to create theories, using experience of the researchers involved in this process. At the same time, it is believed that qualitative methods have a significant potential, since, by using data and examples of social processes, they can provide a lot of information and explanations for the formulated theories and also allow the theory to be generalized to those elements of phenomena that are not subject to quantification [22]. Thus, the theoretical testing using case studies can be assumed. It is also worth paying attention to the fact that the qualitative research is not easier to conduct than the quantitative research and in the past it fulfilled and continues to play an important role in cognitive processes.

Taking into account the above, this paper is dominated by methods characteristic of qualitative research, in particular:

- method of critical literature review and document analysis, allowing e.g. to assess the condition of knowledge in the field of public sector functioning and assets financing, in particular fixed assets [23],

- methods of analysis and synthesis allowing to look for and learn about the influence of various environmental factors and to assess the existing solutions and to generalise and draw conclusions.
The chosen methods were influenced by the subject of research and the purpose of the research. The purchase and implementation of electric buses for operation is a relatively new issue, in many cities the implementation cases are pilot projects. The number or frequency of such or other solutions implemented is not crucial from the point of view of formulated proposals and theories created. It can be added that implementation projects take place simultaneously on several continents and in many countries, including the USA, China and many European countries. In terms of the public bus transport, these countries differ in the division of tasks between the public and private sectors and the adopted principles of urban transport financing. The lack of the well-established methods of financing and more pilot implementation projects result in the search for solutions that are not common but efficient ones, allowing to popularize the zero-emission means of transport and at the same time to spend public funds economically.

\section{Results}

\subsection{The issue of thrift and effective funds spending in the public sector}

The public sector is stronger and stronger present in the daily life, it manifests in multitude of public institutions, a significant number of persons employed and increasingly broad scope of services provided by this sector. Hence there is an ever-stronger need to look for solutions under which the provision of public services of increasingly high standards will be ensured and at the same time this will not require engaging by the public sector of higher and higher funds. Actions aimed at improving efficiency and effectiveness of the public sector functioning should proceed at the same time in many areas. It is possible to mention improvement in the public entities and services management, innovation implementation, provision of services with use of modern technologies, management of public services prices and charges and increasingly better, competent staff [24].

In general, the public sector provides services, which would not be provided in the expected scope and at expected prices by private entities. The public services are frequently provided at prices that do not cover the costs of their provision - lower prices are set on purpose, to increase the demand [25-26] and accessibility of such services, because this results - or according to the assumption should result - in benefits to the society as a whole. Table 4 presents the structure of the main funding sources for urban public transport operating costs in a selection of cities.

Figure 1 presents the cost-coverage ratios for fare revenues and public subsidies in a selection of cities in 2018. The size of each ball represents the relation between the volume of the annual costs of the public 
Table 4 Main funding sources for urban public transport operating costs in a selection of cities in 2012 [27]

\begin{tabular}{cccc}
\hline city and metropolitan area & $\begin{array}{c}\text { coverage by fare revenues } \\
(\%)\end{array}$ & $\begin{array}{c}\text { coverage by public subsidies } \\
(\%)\end{array}$ & $\begin{array}{c}\text { coverage by other revenues } \\
(\%)\end{array}$ \\
\hline Amsterdam & 38.4 & 61.6 & - \\
Barcelona & 48.9 & 51.1 & - \\
Berlin & 55.6 & 44.4 & 25.6 \\
Brussels & 44.9 & 29.5 & 16.8 \\
Budapest & 33.2 & 50.0 & 1.2 \\
Cadiz & 72.4 & 26.4 & - \\
Copenhagen & 54.6 & 45.4 & - \\
Helsinki & 51.3 & 48.7 & - \\
London & 67.6 & 32.4 & 47.5 \\
Lyon & 28.1 & 24.4 & - \\
Madrid & 40.1 & 59.9 & - \\
Montreal & 44.8 & 55.2 & 40.9 \\
Paris & 38.5 & 20.6 & - \\
Prague & 30.8 & 69.2 & 16.9 \\
Stockholm & 38.8 & 44.3 & - \\
Stuttgart & 57.3 & 42.7 & - \\
Turin & 30.7 & 69.3 & 15.4 \\
Vilnius & 48.9 & 35.7 & -
\end{tabular}

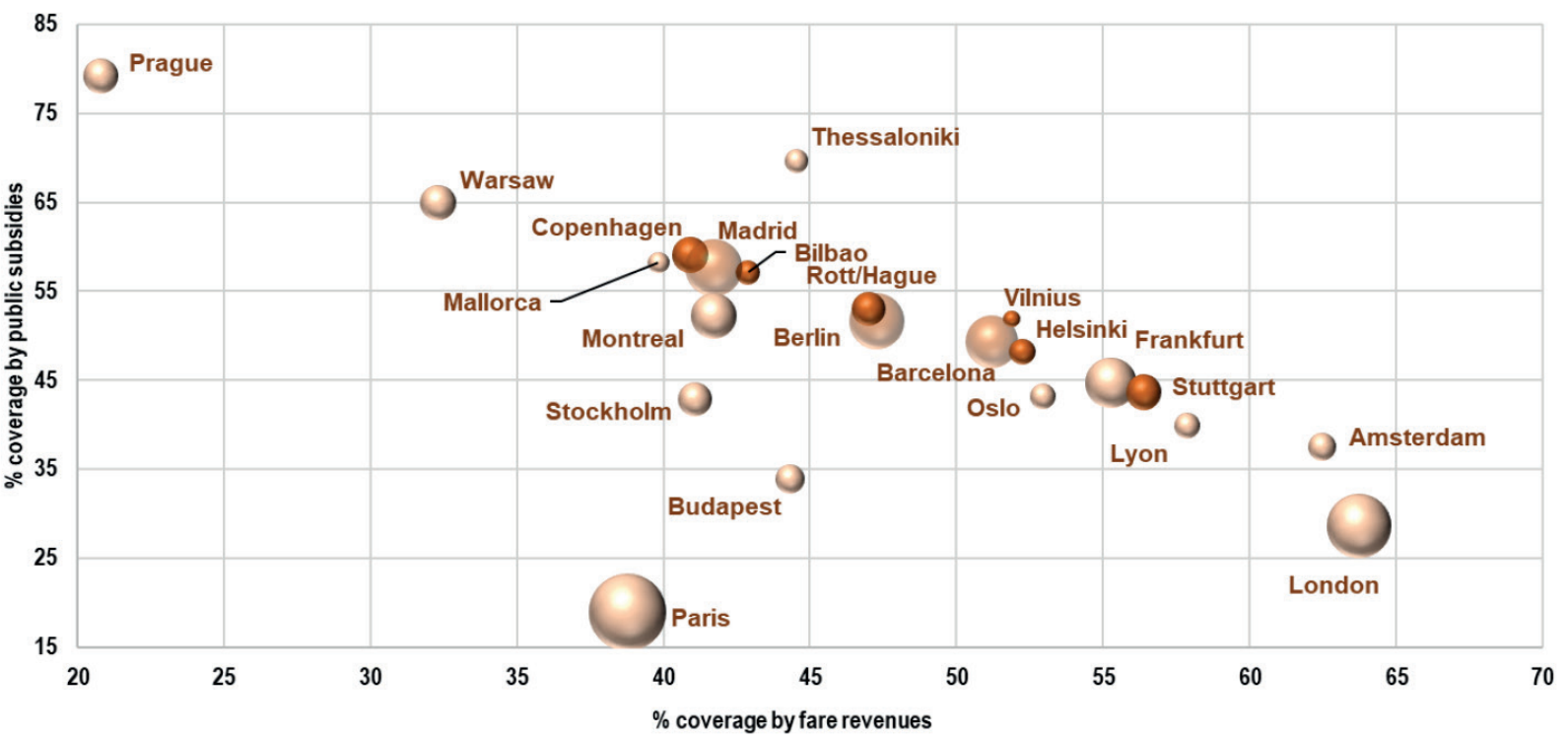

Figure 1 Coverage by public subsidies vs coverage by fare revenues per PTA area inhabitants in 2018 [28]

transport operations and the population of the Public Transport Authority (PTA) area (costs/total inhabitants). The share of the public funds in public transport financing is at a significant level, the average level of public subsidies coverage ratio is $50 \%$ [28].

Frequently, such goods are also made available free of charge, the education or health care services could be used as examples, because an assumption is made that the current civilisation and economic development should guarantee accessibility to such services, irrespective of the economic status. The criterion of exclusivity is another criterion deciding whether the public or private sector is to be responsible for ensuring of a given good provision. Attention should be drawn to the fact that in the case of the urban and regional transport, or transport services in general, the exclusivity is possible, hence if someone does not pay for the service, it is possible to limit the possibility of its use by assumption. So, it is difficult to refer to the necessity of public financing, like it is the case for goods/services, 
in which the exclusivity cannot be ensured (e.g. national defence, local roads).

The setting of prices below the cost of selected services rendering, or ensuring the free access to a part of services, causes that it becomes necessary to ensure such solutions during their provision, which will feature hallmarks of effective. The services, to which access is free, can be rendered by the service provider on a lower level of quality - because the user receives them for free, so (s)he should not make complaints in the field of quality, on the other hand the users can notify demand on the level much higher than their needs and the motive can originate only from the fact that anyhow they are free [5, 29].

At services financing from public funds the issue of justice is raised - a situation occurs, in which funds are redistributed. As a result of tax burdens and later on financing services by funds originating from taxes, people who do not use a specific good, are paying for it, as well. The public financing of urban transport may be an example - public funds originate because of tax burdens also from those, who do not use the urban public transport. Obviously, it is possible to state that due to the public financing of the urban public transport the urban environment is improved and that means benefits to everybody, but this is also relative, to what extent the public financing of the urban public transport increases the demand and to what extent it is only social support for selected social groups, which should obtain such support directly and not by means of prices of urban public transport services. In addition, the effectiveness of support, provided via prices of the public transport services, is debatable - for example not all the elderly persons are poor people, requiring additional financial support.

In general, it should be stated that the term of justness is very relative and vague, more philosophical than economic [30]. However, justice is being sought in many decisions of the public sector, including in the urban public transport, especially in decisions related to entitlements to concessionary and free travelling. However, for practical applications it seems logical to adopt the following rules:

1. The user pays, it is possible to add costs or prices verified by a competitive market. So the costs should be incurred by the users of a specific solution.

2. Benefits can be direct or indirect, e.g. the use of services or only benefiting from the fact that the increase in the demand for such services results, say, in the environmental values improvement.

3. The aid or improvement to the situation of people worst-off, unless it leads to a significant fall in effectiveness or big wastefulness.

Public financing means financing from taxes and high taxes mean, among other things, limitation of the freedom of choice. Decisions on funds spending are made by local, regional, national, or EU level authorities and not independently by specific service users. Such decisions are not always consistent with current preferences and expectations, but, in the situation of the high tax burdens, possibilities of individual choices diminish. The expectations and preferences differ depending among other things on the age, e.g. during the studies or after graduation it is necessary to concentrate funds to purchase or rent an apartment and its indispensable equipment.

Various attitudes to economy of funds spending, depending on whose funds are spent and whose needs satisfied, are noticed in the literature [31]. In a situation when people pay from their own funds for their needs, rational funds spending is then visible. However, if a specific good is financed from other people's funds - other entities or public funds, then, in general, less weight is given to the amount of expenditure. The worst is the situation, when from other people's funds we finance other people's needs and this frequently occurs in the public sector, then the expenditure rationality and effectiveness may be objectively lower [31].

Public funds, hence in general originating from tax burdens, in many cases can be considered nobody's funds; the relationship between the expenditure rationality and later on - in longer - or shorter-time horizon - is not necessarily seen between the amount or even increase in the tax burden. Obviously, all the time via legal regulations, inter alia the obligation of management openness and spending public funds in a purposeful and thrifty way, stipulated in the Act of 27 August 2009 on Public Funds [32], the duty to carry out open competitive tender procedures prior to contract awarding, stipulated in the Act of 29 January 2004 on the Public Procurement Law [33], or even responsibility for the thriftlessness resulting from provisions of the Act of 06 June 1997 on Penal Code [34], rational and effective spending of public funds is sought for. However, via legal regulations, guidelines, or other standards, the effectiveness will not be obtained like in the situation when the direct user pays and expects then a good in accordance with his/her preferences and the entity providing a specific good is subject to market verification.

\subsection{Public sector as the entity financing and providing goods and services}

The public sector provides goods or carries out tasks considered basic, having special importance for the community functioning or conditioning the fulfilment of its basic needs. The scope of such tasks is related to a level of the social and economic development and conditioned by financial capabilities of public budgets. The existence of state, society and its elements' needs (e.g. local population) is an objective phenomenon and their non-fulfilment threatens the existence of society (e.g. national defence, natural environment protection) and of state (e.g. inefficient administration). So, an objective fact of the existence of society and of 
institutions, which are its products (e.g. state, local government authorities), decides about the existence of collective needs [35]. It is possible to mention among tasks, or collective needs considered basic, the health care, social welfare, or education. However, it is difficult to classify the public transport services as such.

Existence of the public interest, which could be accomplished due to such an intervention, is primarily mentioned among premises for regulatory activities undertaken by the public sector. In particular the point is to allocate in a more democratic and efficient way the resources, to ensure accessibility of selected goods - public goods and to increase the market effectiveness [36]. The pursuit of increasingly more democratic and effective allocation of resources means, first of all, the limitation of non-renewable resources use and, what is important in the case of transport activities, reduction of the negative external effects of transport (exhaust gas emission, noise, accidents). It also includes supporting the public transport, because the negative external effects, calculated per transported person, differ in the case of movements carried out by personal cars and means of public transport [37-40]. To reduce the social costs of transport and to trigger the behaviour, in which rare resources are used thriftily, it is proper to apply the "user pays" principle. This means charging the users, at least partly, with external costs originated due to the movements and generation of adverse effects in the environment. Identification of the external costs level remains the issue, which - depending on the place of activity, surroundings and other factors - are different and also ensuring of the fees collection in such a way as to connect the amount of fee with amount of the generated external costs. It is natural that the goods users are not willing to pay voluntarily for the negative effects of their activity, transferred onto third persons or goods consumed collectively. Therefore, only regulatory actions, through burdening with external costs, can contribute to reduction of undesirable external effects of the carried out transport activity. Another issue, related to an economical use of rare resources, is the fact that processes occurring on the markets would not always ensure proper supply, situations of selected goods overproduction are possible, e.g. oversupply of public transport services, hence services utilising rare resources (liquid fuels, environmental pollution) during their provision. The limitation of such situations is expected through the public administration intervention [37].

Attention should be also drawn to the fact that, deliberately or not, the market role limitation and thereby limitation of decisions on provided services, made by direct users, results in funds transfers/redistribution between various social groups. As a result, persons not using a specific service are also burdened (via tax burdens or other obligatory charges [41]) with the costs [37], which takes place, e.g. in the situation of subsidising from public funds the passenger transport by urban and regional public transport. Moreover, redistribution of funds occurs in the urban or regional public transport during the provision of transport services to areas of small passenger flows (e.g. city outskirts) and thereby generating a substantial deficit of funds and this service is financed by the revenue from more loaded lines/ areas (city centres), where selected lines could be even profitable. This fact is not considered at the prices setting, especially criteria of their diversification. Hence, a part of regulatory activities may be explained also as an indirect form of taxation.

\section{Sources and financing models of electric buses purchase - discussion of study results}

\subsection{Investment financing from operators depreciation and profits and directly by municipalities/organisers}

Depreciation charges and accumulated profits should be included among basic financing sources of entities fixed assets. By their nature, depreciation charges should constitute the basic source of replacement investments financing. The investing of entities profits should be a supplementary financing source of simple reproduction and as a rule - the source of expanded reconstruction. However, in the case of the public services provision, which are usually provided below costs, i.e. the obtained revenues are lower than own costs of entities, the financial result and hence profits, if any, depend on the amount of public financing. Hence, one can talk here primarily about depreciation as a source of assets reconstruction. In this solution:

- the size of investments is adjusted to the size of service sales,

- the decision about investing is made by an operator, but also by organisers, who decide about requirements set to operators, which is reflected in provisions comprised by the contracts,

- the operator is the owner of assets acquired as a result of investing based on depreciation and possibly profit, so the issues of improper care of the acquired assets are limited,

- operators obtain higher accumulation more effectively and are in a position to allocate more funds to development.

In the case of the public sector operators, it is necessary to apply solutions of funds management control, e.g. via the ownership supervision, since one can encounter unused investment possibilities and/ or consumption of achieved profit, in a direct form or through costs inflation. A possible solution consists of privatisation of the urban public transport operators. Another issue, limiting investment possibilities, is a situation of inappropriate cost structure and too small depreciation, amount of which does not allow even for a simple reproduction. This can result from the 
following reasons:

- operators use depreciated assets and overestimation of the fixed assets value deviates from the price increase on the market,

- technical progress, market and environmental protection requirements cause (electric buses case) that means of production available on the market have better design solutions and thereby a higher price.

Because of the aforementioned reasons a part of investments must be based on retained earnings, or on repayable or non-repayable financing sources. However, it is worth drawing attention to the fact that the profit is burdened with an income tax. Hence the profit generation by operators implies the necessity to pay out a part of funds in the form of corporate income tax (in Poland to the state budget, from which only a small part feeds municipality budgets). An urban public transport is financed from public funds and just the amount of this financing decides about operators profitability. So, the investing from profits does not guarantee an effective use of funds assigned to investments. That means that depreciation and obtained profits, if any, have limited usefulness in the case of the capital-intensive development investments, e.g. electric buses purchase and must be supported by other solutions. The financing of investments from depreciation and achieved profits requires that the entity financing urban public transport approves an increased amount of the co-financing for the transport services provision and hence in its nature it boils down to financing purchases from the public budgets funds, however, in a system of funds flow through the operator carrying out the transport.

For the purchase needs of electric buses - more expensive that traditional buses - a system was created in which operators finance purchases in a mixed solution. They buy an electric bus, but without a battery - the cost of which is a significant part of the bus price - at a price similar to a price of a traditional bus purchase, but they use batteries on a principle of leasing $[1,9,18]$. This solution may be favourable for a number of reasons. First - the purchase order price of an electric bus does not differ significantly from the purchase price of a traditional bus, which means that the purchase may be financed from the depreciation fund and at the moment of purchase it does not disturb the entity's financial management. Another premise is the fact that battery financing is distributed over time and the leasing instalment paid may be included in costs, moreover, funds for its financing at least a part can originate from a decrease of electric bus operating costs as compared with a traditional bus. One can refer here to the lower electricity costs against fuel costs and also lower costs of maintenance and repairs - because of a simpler design of many components of the electric bus drive. Obviously, depending on the country and level of liquid fuels and electricity prices and also of those energy carriers purchase system, existing there, the costs reductions and thereby benefits obtained from such a solution will differ. In addition, one more benefit is obtained - risks related to potential reduction of battery durability or its parameters, below figures specified in the contract, are on the lessor's side.

Solutions consisting in a direct purchase of vehicles from budgetary funds by a municipality or another public unit and handing them over to the operator for use are also possible. An advantage of such a solution consists of using for investments all the funds allocated to this purpose, without limitations related to income tax burdens. Moreover, on this level vehicles may be purchased altogether for a few operators, because of which - due to economies of scale - unit prices may be lower. This solution may be preferred also in the case of acquiring the external co-financing. It is necessary to emphasise that in such a solution the link between the actual economic efficiency of the operator and its development possibilities is broken. Moreover, in a situation where transport in a given area is carried out by a few or a dozen or so bus operators, a problem originates of equal, as a rule, operators access to purchased vehicles. No privileged access, e.g. for publicly owned operators, shall be applied here, because the market costs verification would be lost. Another issue is the fact that operators are released this way (those acquiring vehicles in such a way) from the obligation to achieve appropriate accumulation Since the nonrepayable handing over of fixed assets creates a problem of their efficient operation. As a result, an unjustified increase in the investments demand can occur. It will result from reduction of expenditures on the current maintenance of the received asset, leading thereby to its premature wear, resulting from the fact that the received asset did not cost the operator anything.

Another method of investment projects financing in commercial law companies consists in increasing the equity through shares issuing or additional equity contributions of hitherto and new shareholders. The increased amount of equity, available to the company, increases its investment possibilities, which in turn enables introducing the zero-emission vehicles and expansion of the scope of services provided, in accordance with the demand. The basic advantage of the solution consists of a possibility to introduce significant amounts of equity to operators, without inconveniences related to passing funds through the P\&L account. The issue of capital availability is the main disadvantage.

Assuming the public ownership of operators carrying out the transport it is possible - apart from electric buses purchase - to indicate other situations, as well, in which the public entities will be interested in injecting capital to operators, i.e.:

- expansion of provided services scope due to land development and origination of the new traffic origins and destinations served by the public transport,

- change of the ownership structure and owners 
influence on a given entity management,

- improvement in the entity competitiveness, its financial standing and in the future selling shares or stocks to non-municipal entities.

Attention is drawn to the fact that in the case of many owners, existence of various opinions can appear related to the capital injection need. This will result from a diversified financial situation of public entities, various needs and preferences in the field of allocation and thereby spending the funds available, as well as adopted standards of population needs satisfying in the field of the urban public transport. In addition, limitations related to public aid issues should be considered.

\subsection{External financing sources}

External financing sources may be divided into repayable and non-repayable. Obviously, the nonrepayable ones are the most attractive, they allow to co-finance purchases - most often a significant part of the total funds spent on the investment, without the obligation to return them. A possibility to obtain the non-repayable co-financing occurs most frequently during the implementation of projects, which are not profitable and, at the same time, as a result of which substantial external benefits may be achieved, e.g. related to the environmental protection, as in the case of zero-emission public transport [42]. Special-purpose funds are created, or programmes under which such funds are acquired. Funds and programmes may be national or created within larger integration groups, e.g. the European Union.

In the situation, in which it is not possible to use the non-repayable financing, the financing from repayable sources remains. Credit is one of repayable investment financing sources. The use of credit for investment financing enables obtaining the effect of financial leverage. Operators, increasing their capital, increase assets and as a result can increase their profits. Other advantages of credit use include:

- possibility to incur substantial capital expenditures in a relatively short time,

- investments are implemented directly by the operator, who is most interested in rationality and rightness of purchases made,

- purchased goods are owned by the operator, which provides premises for due care of them and does not violate the balance between expenditures on goods purchase and their maintenance.

Credit is now pretty seldom used by operators to finance investments. It results, among other things, from concerns related to a high credit costs and, as a result, to financial costs growth. Another reason, in the case of projects resulting in benefits in the field of environmental protection, is the fact of non-repayable funds availability.
The use of credit each time requires an analysis taking into account:

- the amount of capital expenditure,

- the inflation rate and credit interest rate,

- possibility to achieve, as a result of investment, operating costs cutting,

- increased services supply and their improved quality.

The credit may be taken by operators or owners e.g. public sector entities. If credit is taken by owners, it is possible to release the non-repayable financing by these entities.

In addition, bonds may be used, apart from the credit. Bonds can be issued both by the public sector entities, e.g. municipal bonds [43] and by operators. The bond issuer may commit to provide specified services to the bonds holder. Basic advantages of bonds use may include:

- substantial expansion of the scope of potential lenders; bonds may be purchased both by financial institutions and banks and by other enterprises and private individuals, as well,

- bonds give an opportunity to acquire substantial capital, frequently impossible to obtain under a bank loan,

- it is possible to force the bond issuer to provide the bond holder with specific benefits,

- the payment for services may be partially made using bonds.

It is necessary to emphasise that in the case of bonds purchase, e.g. by a public transport organiser, a mutual dependence between the organiser and bond issuer, i.e. operator, occurs. On the other hand, however, the organiser buying bonds can secure itself against an excessive rise in provided services price, by the use of indexed bonds.

The next source of acquiring new vehicles from outside consists in operation of vehicles owned by others, e.g. according to the leasing rules. The carrier (lessee) then uses vehicles for the payment of the leasing rate. Financial efficiency of this project depends on the contract signed by and between the carrier and the lessor, since the object of leasing can be shown in lessor's or lessee's assets. Attention is also drawn to the fact that a lessor may be a transport organiser, as well as entities operating in accordance with commercial rules. An electric bus, but also - what was emphasised before - electric bus batteries, may be the object of leasing. Leasing is considered an attractive financing tool, allowing to reduce the funds spent at the beginning of a purchase project and to distribute costs over time.

\subsection{Applicability of research results and implications for managerial practice}

There are different organizational and ownership solutions in the urban public transport in cities 
worldwide. Involvement of the public administration varies, from the direct provision of services by public entities to being a regulator and commissioning the provision of services and, in some cases, also the management of urban transport. There are also different financing systems of investments and ongoing operations of municipal public transport services. However, irrespective of this, the formulated rules for implementation and financing of electric buses can be applied in various organizational systems of public transport. The key criteria used in their formulation included significant environmental benefits in cities resulting from the zero-emission of electric vehicles and the search for effective solutions to spend the funds, applicable to private entities. The same is valid especially for the public entities, as they spend public funds and at the same time there is no market verification of the services provision costs. Thus, the proposed solutions, as based on the principles of economic and effective spending of funds, are not limited to specific organizational solutions and are not limited to selected countries or cities. For example, they are used both in deregulated and privatized public transport in some cities - for example in the United Kingdom, or in publicly owned and privatized management - like in France, as well as in public entities of urban transport, e.g. in Germany, Poland or Slovakia.

Intensification of purchases and implementation of electric buses, as currently more expensive vehicles than traditional buses, require actions at the levels of transport policy, urban public transport management and the provision of transport services. At the level of the transport policy and the management of public urban transport systems, those require creating programmes and funds that can be used for non-returnable financing of purchases of the zero-emission vehicles. Moreover, when entrusting the provision of services (whether by way of an open competitive procedure or by direct entrustment), the assessment criteria should take into account minimization of the environmental impact and $\mathrm{CO}_{2}$ emissions in addition to the rate or subsidy to the operating work unit. This will allow the environmental benefits to be balanced against increased public funding. Operators' activities should focus on several directions. The first one is associated with the maximum use of purchased electric buses, despite the increased downtime related to battery recharging. This means directing these vehicles to lines with significant maintenance times, moreover, lines running mainly in the city centres, where environmental aspects are of the greatest importance. The second direction is related to use at purchasing of such financial solutions, which costs will be as low as possible. This means, as far as possible, use of external, non-returnable sources of financing, or, if such are not available, interest-free (no-costs) credits related to environmental protection, irrespective of the previous battery lease solutions with which buses are equipped.

\section{Conclusions}

Introduction of the city servicing by electric buses means not only challenges related to the manufacturing technology of buses, batteries used by them and their range, creation of battery charging infrastructure and appropriate technical facilities in entities operating such vehicles, but ensuring the appropriate funds, as well, since all those require involvement of substantial funds, including the purchase of electric buses themselves. Services of the urban public transport are public services and the revenue obtained on their sales does not cover the incurred costs - co-financing from public funds is used here, most frequently originating from municipality budgets. Electric buses, as the zero-emission vehicles, allow to obtain the significant external benefits, hence involvement of public funds is advisable and because of buses high costs of purchase - indispensable. Use of the public funds in a special way should obligate to spend funds purposefully and thriftily. It is necessary to show here the search for solutions allowing for effective management of transport and tariffs, ticket inspections and effective recovery of additional charges, as well as implementation of innovations improving the other areas of organisers and operators activity, so that the obtained savings and free funds could be used for emission reduction.

When performing the financial analyses and assessments of electric buses implementation it is suggested to consider the costs incurred during the whole period of vehicles operation and not only those related to their purchase. This criterion should be taken into account and not only at the stage of the feasibility studies preparation, but, if possible, during the bids evaluation in tenders for the new buses procurement, as well. However, the purchase price was taken so far as a significant criterion of entity's choice at procurement of vehicles.

The depreciation write-offs should be the basic source of financing the replacement investments by the bus operators. Adhering to this principle has many advantages, the volume of purchases results from the actual needs related to transport services, more efficient operators have greater accumulation and therefore more funds can be spent on investment purchases and development and the operator is the owner of the property, which eliminates problems of the proper care for the acquired property. However, there is a problem with undertaking development investments and those in which the market and environmental protection requirements force the purchase of vehicles at a significantly higher price - and this is today the case of electric buses. The operators should then assign their profit and when it is not generated, it becomes necessary to use external sources - returnable or non-returnable. In the case of returnable sources, it will be necessary to obtain the higher subsidizing of services provision from public funds. 
Prices of electric buses are much higher than of traditional ones, hence the depreciation funds, established by operators, is not sufficient. It is advisable - to a possible extent - to use the non-repayable funds during the procurement, which are aimed at supporting the lowemission transport and modernisation of the transport potential of the urban public transport. Bus purchases may originate also from repayable funds, e.g. a loan or bond issue, where a part of the credit costs may be also refinanced from funds related to the environmental protection and transport modernisation. In addition, the leasing solutions for batteries used by buses are attractive; in this way the demand for funds is reduced at the moment of procurement, as well as the risk of improper quality and durability of the battery itself.

Irrespective of funding sources themselves, it is necessary to implement solutions, in which the purchased vehicles will be effectively used so that the very fact of acquiring means of transport at prices lower than the market ones would not result in deterioration of their care, e.g. pursuing the service costs cutting. It is also necessary to ensure financing of provided services and carrying out an appropriate financial-accounting policy, so that after those means wear, the depreciation charges in the next cycle would allow to buy the next batteries and buses themselves.

\section{References}

[1] Electric buses arrive on time. Marketplace, economic, technology, environmental and policy perspectives for fully electric buses in the EU. A study by Transport and Environment [online] [accessed 2020-06-01]. November 2018. Available from: https://www.transportenvironment.org/sites/te/files/publications/Electric\%20buses\%20 arrive\%20on\%20time.pdf

[2] U. S. Energy Information Administration. Short-Term Energy Outlook (STEO) Independent Statistics and Analysis [online] [accessed 2020-03-01]. February 2020. Available from: https://www.eia.gov/outlooks/steo/

[3] NOWICKI, M. Undepletable energy in the light of depletable minerals / Niewyczerpywalna energia w swietle wyczerpywalnych kopalin (in Polish). Institute for Market Economy Research, Centre for Energy Strategies / Instytut Badan and Gospodarka Rynkowa, Centrum Strategii Energetycznych [online] [accessed 2020-03-01]. December 2012. Available from: https://cse.ibngr.pl/niewyczerpalna_energia_w_swiecie_wyczerpywalnych_ kopalin/

[4] RUIZ-MONTANES, M. Financing public transport: a spatial model based on city size. European Journal of Management and Business Economics [online]. 2017. 26(1), p. 112-122 [accessed 2020-04-01]. ISSN 2444-8494. Available from: https://doi.org/10.1108/EJMBE-07-2017-007

[5] DYDKOWSKI, G., TOMANEK, R., URBANEK, A. Tariffs and toll collection systems in municipal public transport / Taryfy $i$ systemy poboru oplat w miejskim transporcie zbiorowym (in Polish). Katowice: Wydawnictwo Uniwersytetu Ekonomicznego w Katowicach, 2018. ISBN 978-83-7875-440-4.

[6] ORBEA, J., CASTEllanOS, S., ALBUQUERQUE, C., SClAR, R., PINHEIRO, B. Adapting procurement models for electric buses in Latin America. Transportation Research Record: Journal of the Transportation Research Board [online]. 2019, 2673(10), p. 175-184 [accessed 2020-03-10]. ISSN 0361-1981, eISSN 2169-4052. Available from: https://doi.org/10.1177/0361198119846097

[7] WYSZOMIRSKI, O., WOLEK, M., JAGIELLO, A., KONIAK, M., MARTLOMIEJCZYK, M., GRZELEC, K., GROMADZKI, M. Electromobility in the public transport, Guide for local governments, public enterprises and private carriers. Practical aspects of implementation / Elektromobilnosc w transporcie publicznym. Przewodnik dla jednostek samorzadu terytorialnego, przedsiebiorstw uzytecznosci publicznej i prywatnych przewoznikow. Praktyczne aspekty wdrazania (in Polish) [online] [accessed 2020-03-10]. Special report. Warsaw: Polish Development Fund and Polish Alternative Fuels Association, 2018. Available from: http://pspa.com.pl/assets/ uploads/2018/12/raport_PFR_elektromobilnosc_w_transporcie_S.pdf

[8] HOOFTMAN, N., MESSAGIE, M., COOSEMANS, T. Analysis of the potential for electric buses [online] [accessed 2020-03-10]. A study accomplished for the European Copper Institute. Vrije Universiteit Brussel. Available from: https://leonardo-energy.pl/wp-content/uploads/2019/02/Analysis-of-the-potential-for-electric-buses.pdf

[9] Pay as you save for clean transport. Instrument Analysis. Global Innovation Lab for Climate Finance, September 2018 [online] [accessed 2020-03-10]. Available from: https://climatepolicyinitiative.org/wp-content/ uploads/2018/10/PAYS-for-Clean-Transport_Instrument-Analysis.pdf

[10] Directive (EU) 2019/1161 of the European Parliament and of the Council of 20 June 2019 amending Directive 2009/33/EC on the promotion of clean and energy-efficient road transport vehicles. Official Journal of the European Union L/188/116 [online] [accessed 2020-03-10]. Available from: https://eur-lex.europa.eu/legalcontent/EN/TXT/PDF/?uri=CELEX:32019L1161\&from=EN

[11] Electric bus fleets in Europe. Three turbulent effects that will dominate in the rapid electrification of our public transport. Perspectives, March 2019 [online] [accessed 2020-04-10]. Available from: https:/www.accuracy.com/ wp-content/uploads/2020/01/Perspectives-Print-Electric-bus-v1_anglais.pdf 
[12] LI, X., CASTELlanOS, S., MAASSEN, A. Emerging trends and innovations for electric bus adoption a comparative case study of contracting and financing of 22 cities in the Americas, Asia-Pacific and Europe. Research in Transportation Economics [online]. 2018. 69, p. 470-481 [accessed 2020-11-10]. ISSN 0739-8859. Available from: https://doi.org/10.1016/j.retrec.2018.06.016

[13] SIOSHANSI, F., WEBB, J. Transitioning from conventional to electric vehicles: The effect of cost and environmental drivers on peak oil demand. Economic Analysis and Policy [online].2019, 61(C), p. 7-15. ISSN 0313-5926. Available from: https://doi.org/10.1016/j.eap.2018.12.005

[14] JATTIN, M. G. Financial mechanisms for electric bus. Germany, Eschborn: Deutsche Gesellschaft fur Internationale Zusammenarbeit (GIZ) GmbH on behalf of the Federal Ministry for Environment, Nature Protection and Nuclear Safety of the Federal Republic of Germany, 2019.

[15] LI, X., GORGUINPOUR, C., SCLAR, R., CASTELlANOS, S. How to enable electric bus adoption in cities worldwide. A guiding report for city transit agencies and bus operating entities. Washington DC: World Resources Institute Ross Center, 2019 [online] [accessed 2020-11-10]. Available from: https://wrirosscities.org/ research/publication/how-enable-electric-bus-adoption-cities-worldwide

[16] SCLAR, R., GORGUINPOUR, C., CASTELlANOS, S., LI, X. Barriers to adopting electric buses. Washington DC: World Resources Institute Ross Center, 2019 [online] [accessed 2020-11-10]. Available from: https://wrirosscities.org/sites/default/files/barriers-to-adopting-electric-buses.pdf

[17] MILLER, J., MINJARES, R., DALLMANN, T., JIN, L., Financing the transition to soot - free urban bus fleets in 20 megacities. Confederazione Svizzera: The International Council on Clean Transportation, Climate and Clean Air Coalition to Reduce Short-Lived Climate Pollutants, 2017 [online] [accessed 2020-04-10]. Available from: https://theicct.org/sites/default/files/publications/Soot-Free-Bus-Financing_ICCT-Report_11102017_vF.pdf

[18] MOON-MIKLAUCIC, CH., MAASSEN, A., LI, X., CASTELLANOS, S., Financing electric and hybrid-electric buses: 10 questions city decision-makers should ask. Working Paper. World Resources Institute, October 2019 [online] [accessed 2020-04-10]. Available from: https://wrirosscities.org/sites/default/files/financing-electrichybrid-electric-buses.pdf

[19] RUSSELL BERNARD, H. Social research methods: qualitative and quantitative approaches. Los Angeles, London, New Delhi, Singapore, Washington D.C.: Sage Publications, Inc., 2013. ISBN 978-1412978545.

[20] MINTZBERG, H. An emerging strategy of “direct" research. Administrative Science Quarterly [online]. 1979, 24, p. 582-589 [accessed 2020-11-10]. ISSN 0001-8392. Available from: https://doi.org/10.2307/2392364

[21] SHAH, S., CORLEY, K. Building better theories by bridging the qualitative-quantitative divide. Journal of Management Studies [online]. 2006, 43(8), p. 1821-1835 [accessed 2020-11-10]. eISSN 1467-6486. Available from: https://doi.org/10.1111/j.1467-6486.2006.00662.x

[22] BITETKINE, A. Prospective case study design. qualitative method for deductive theory testing. Organizational Research Method. Sage Publications, 2007 [online] [accessed 2020-11-10]. Available from: https://citeseerx.ist. psu.edu/viewdoc/download?doi=10.1.1.117.8867\&rep=rep1\&type=pdf

[23] BOWEN, G. A. Document analysis as a qualitative research method. Qualitative Research Journal [online]. 2009, 9(2), p. 27-40 [accessed 2020-11-10]. ISSN 1443-9883. Available from: https://doi.org/10.3316/QRJ0902027

[24] DYDKOWSKI, G., OKON, J. Partnerstwo publiczno-prywatne jako narzedzie korzystania z kapitalow prywatnych i efektywnej realizacji zadan publicznych. Studia Ekonomiczne. Zeszyty Naukowe Uniwersytetu Ekonomicznego w Katowicach. 2017, 316, p. 57-69. ISSN 2083-8611.

[25] GNAP, J., KONECNY, V., POLIAK, M. Elasticity of demand in mass passenger transport. Journal of Economics. 2006. 54(7). p. 668-684. ISSN 0931-8658. eISSN 1617-7134.

[26] URBANEK, A. Public transport fares as an instrument of impact on the travel behaviour: an empirical analysis of the price elasticity of demand. In: SUCHANEK, M. (ed) Challenges of urban mobility, transport companies and systems [online]. TranSopot 2018. Springer Proceedings in Business and Economics. Cham: Springer, 2019. ISBN 978-3-030-17743-0. p. 101-113. Available from: https://doi.org/10.1007/978-3-030-17743-0_9

[27] TURRO, M., PONS, A., SAURI, S., PENYALVER, D., BUSQUETS, M., GUTBERLET, T., KRITZINGER, S. Pilot project study on innovative ways of sustainably financing public transport. Final Report. Cenit, Prognos, COWI, European Commission, Directoriate general for Mobility and Transport, 2018 [online] [accessed 2020-0410]. Available from: https://www.emta.com/spip.php?article267\&lang=en

[28] EMTA Barometer 2020 - Based on 2018 data, Paris [online] [accessed 2020-06-16]. Available from: https://www.emta.com/spip.php?article267\&lang=en

[29] DYDKOWSKI, G., GNAP, J., Premises and limitations of free public transport implementation. Communications - Scientific Letters of the University of Zilina [online]. 2019, 21(4), p. 13-18. ISSN 13364205, eISSN 2585-7878. Available from: https://doi.org/10.26552/com.C.2019.4.13-18

[30] DYDKOWSKI, G. The application of just distribution theories to financing integrated systems of regional and urban public transport. Scientific Journal of Silesian University of Technology. Series Transport [online]. 2018, 100, p. 23-33. ISSN 0209-3324. Available from https://doi.org/10.20858/sjsutst.2018.100.3 
[31] FRIEDMAN, M., FRIEDMAN, R. Free to choose: a personal statement. New York and London: Harcourt Brace Jovanovich Inc., 1980. ISBN 0-15-133481-1.

[32] Act of 27 August 2009 on Public Finance, Unified text: Dz. u. of 2019, item 869, 1622, 1649 and 2020 / Ustawa z dnia 27 sierpnia 2009 roku o finansach publicznych, Tekst jednolity Dz. u. 2019, poz. 869, 1622, 1649, 2020 (in Polish) [online] [accessed 2020-04-10]. Available from: http://prawo.sejm.gov.pl/isap.nsf/download.xsp/ WDU20091571240/U/D20091240Lj.pdf

[33] Act of 24 January 2004 - Public Procurement Law, unified text Dz. u. of 2019, item 1843 / Ustawa z 24 stycznia 2004 r. Prawo zamowien publicznych. Tekst jednolity Dz. u. z 2019, poz. 1843 (in Polish) [online] [accessed 202004-10]. Available from: http://prawo.sejm.gov.pl/isap.nsf/download.xsp/WDU20040190177/U/D20040177Lj. pdf

[34] Act of 6 June 1997 on Penal Code, unified text Dz. u. of 2018, item 1600, 2077 / Ustawa z dnia 6 czerwca 1997 r. kodeks karny, tekst jednolity Dz. u. z 2018 roku, poz. 1600, 2077 (in Polish) [online] [accessed 2020-04-10]. Available from: http://prawo.sejm.gov.pl/isap.nsf/DocDetails.xsp?id=WDU19970880553

[35] OWSIAK, S. Public finance. Theory and practice / Finanse publiczne. Teoria i praktyka (in Polish). Warsaw: PWN, 2005. ISBN 978-83-011-5732-6.

[36] KAMERSCHEN, D. R., MCKENZIE, R. B., NARDINELLI, C. Economics / Ekonomia (in Polish). Gdansk: Fundacja Gospodarcza NSZZ Solidarnosc, 1999. ISBN 83-00-03545-1.

[37] TOMANEK, R. Competitiveness of urban transport / Konkurencyjnosc transportu miejskiego (in Polish). Katowice: Wydawnictwo Akademii Ekonomicznej, 2002. ISBN 83-7246-199-6.

[38] VAN ESSEN, H., SCHROTEN, A., OTTEN, M., SUTTER, D., SCHREYER, CH., ZANDONELLA, R., MAIBACH, M., DOLL, C. External costs of transport in Europe. CE Delft, INFRAS Fraunhofer ISI, September 2011 [online] [accessed 2020-04-10]. Available from: https://www.cedelft.eu/publicatie/external_costs_of_transport_in_ europe $/ 1258$

[39] BECKER, U. J., BECKER, T., GERLACH, J. The true costs of automobility: external costs of cars overview on existing estimates in EU 27. Technische Universitat Dresden [online] [accessed 2020-04-10]. Available from: https://stopclimatechange.net/fileadmin/content/documents/move-green/The_true_costs_of_cars_EN.pdf

[40] External costs of transport in Central and Eastern Europe. OECD, Central European Initiative, Austrian Federal Ministry of Agriculture, Forestry, Environment and Water Management, Paris, Trieste, Vienna [online] [accessed 2020-05-10]. Available from: http://www.oecd.org/greengrowth/greening-transport/29403950.pdf

[41] POLIAK, M., SEMANOVA, S., MRNIKOVA, M., KOMACKOVA, L., SIMURKOVA, P., POLIAKOVA, A., HERNANDES, S. Financing public transport services from public fonds. Transport Problems [online]. 2017, 12(4). p. 61-72. eISSN 2300-861X. Available from: https://doi.org/10.20858/tp.2017.12.4.6

[42] GLOTZ-RICHTER M., KOCH H. Electrification of public transport in cities (Horizon 2020 ELIPTIC Project). Transportation Research Procedia [online]. 2016, 14. p. 2614-2619 [accessed 2020-11-10]. ISSN 2352-1465. Available from: https://doi.org/10.1016/j.trpro.2016.05.416

[43] CASALE, M., MAHONEY, B. Paying for electric buses. financing tools for cities and agencies to Ditch Diesel. U.S. PRIG Education Fund, Fall 2018 [online] [accessed 2020-06-10]. Available from: https://uspirg.org/sites/ pirg/files/reports/National\%20-\%20Paying\%20for\%20Electric\%20Buses.pdf 